\title{
CD147 functions as the signaling receptor for extracellular divalent copper in hepatocellular carcinoma cells
}

\author{
Pengfei Ding ${ }^{1, *}$, Xin Zhang ${ }^{2,}{ }^{*}$, Shujuan Jin ${ }^{1}$, Bo Duan ${ }^{1}$, Pengxiang Chu ${ }^{1}$, Yufei \\ Zhang ${ }^{1}$, Zhi-Nan Chen ${ }^{2}$, Bin Xia ${ }^{1}$ and Fei Song ${ }^{2}$ \\ ${ }^{1}$ Beijing Nuclear Magnetic Resonance Center, School of Life Sciences, College of Chemistry and Molecular Engineering, \\ Peking University, Beijing 100871, China \\ ${ }^{2}$ Department of Cell Biology, State Key Laboratory of Cancer Biology, Cell Engineering Research Center, The Fourth Military \\ Medical University, Xi'an 710032, China \\ *These authors contributed equally to this work
}

Correspondence to: Bin Xia, email: binxia@pku.edu.cn

Fei Song, email: fei.cabm@yahoo.com

Keywords: CD147, extracellular divalent copper, matrix metalloproteinase, invasion, hepatocellular carcinoma

Received: January 13, 2017 Accepted: April 24, $2017 \quad$ Published: May 09, 2017

Copyright: Ding et al. This is an open-access article distributed under the terms of the Creative Commons Attribution License 3.0 (CC BY $3.0)$, which permits unrestricted use, distribution, and reproduction in any medium, provided the original author and source are credited.

\section{ABSTRACT}

Elevated copper levels in tumor microenvironment are directly correlated to cancer progression in a variety of malignancies. Copper is required in angiogenesis, and promotes the proliferation and metastasis of cancer cells. However, the molecular mechanism of copper in promoting cancer progression remains elusive. Here we report that CD147 serves as a signaling receptor for extracellular $\mathrm{Cu}^{2+}$ in hepatocellular carcinoma (HCC) cells. $\mathrm{Cu}^{2+}$ binds to the extracellular membrane-proximal domain of $\mathrm{CD} 147$ and mediates its self-association. $\mathrm{Cu}^{2+}$-mediated self-association of CD147 activates PI3K/Akt signaling pathway leading to the up-regulation of matrix metalloproteinase MMP-2 and MMP-14 in HCC cells. $\mathrm{Cu}^{2+}$-induced CD147 selfassociation also enhances the ability of HCC cells to stimulate MMP-2 expression from neighboring fibroblasts, as well as increases the invasiveness of HCC cells which is abolished by the copper chelator tetrathiomolybdate. We have mapped the interfaces and identified the key residues of $\mathrm{CD} 147$ involved in the $\mathrm{Cu}^{2+}$ induced self-association. The $\mathrm{Cu}^{2+}$ binding deficient $\mathrm{CD} 147$ mutant abolishes the stimulating effects of $\mathrm{Cu}^{2+}$ on HCC cells. Our study reveals a novel extracellular signaling role of copper in promoting cancer cell metastasis, which implies that targeting the $\mathrm{Cu}^{2+}$-induced self-association of CD147 is a new strategy for cancer treatment.

\section{INTRODUCTION}

Copper, an essential transition metal for life, serves as an important structural and catalytic cofactor involved in a diverse series of biochemical processes [1]. Elevation of copper in serum and cancer tissues are found in patients with a wide variety of malignancies, such as lymphoma, reticulum cell sarcoma, cervical, stomach, ovarian, lung, prostate, breast and liver cancer, and is directly correlated to cancer progression [2]. Copper has long been known to promote angiogenesis [3], and was shown to directly stimulate proliferation and invasion of cancer cells $[4,5]$. Over a dozen clinical trials have been carried out for copper-lowering anti-cancer therapies [6-10], and it was recently reported that copper depletion by a potent copper chelator tetrathiomolybdate (TM) shows a striking effect in the treatment of triple negative breast cancer in a phase II clinical trial [11, 12].

Up to date, the molecular mechanism of copper in promoting cancer progression is still poorly understood. A large number of pro-angiogenic factors have been shown to be copper dependent [13]: copper may directly bind to angiogenic growth factors, such as angiogenin, and increase their affinity for endothelial cells [14]; copper may control the secretion of angiogenic cytokines, as demonstrated with bFGF and IL-1 $\alpha$ [15]; copper may 
induce the expression of angiogenic growth factor such as VEGF $[16,17]$. However, the direct causative connection and clear molecular basis for the high sensitivity of angiogenesis to copper has not been reached. For other stimulating effects of copper on cancer cells, studies have mainly focused on the roles of intracellular copper as cofactors of enzymes [18]. Intracellular copper is the catalytic cofactor of Memo which plays a critical role in cell motility [19]. It was recently reported that intracellular copper is required for oncogenic BRAF signaling and tumorigenesis [20]. On the other hand, it was found that extracellular divalent copper $\left(\mathrm{Cu}^{2+}\right)$ is essential for the activities of both lysyl oxidase and lysyl oxidase-like proteins, which are directly related to cancer cell metastasis [21]. A recent study elegantly showed that the elevation of copper in blood of hepatocellular carcinoma (HCC) patients is not of exogenous origin, and is suggested to be released from intracellular copper storages [22]. Furthermore, it was found that $80-90 \%$ of intracellular copper are translocated into the extracellular space of the leading edge of endothelial cell projections during angiogenesis [23]. These redistributed copper ions were suggested to bind to and activate yet unknown cell surface receptors or extracellular targets [3].

CD147 (also known as Basigin) is a type I transmembrane glycoprotein with two immunoglobulin (Ig)-like domains [24-28]. It is widely expressed in human tissues and has been implicated in many physiological and pathological processes [29, 30]. Particularly, CD147 is highly-enriched on the surface of a wide variety of malignant tumor cells, including all the cancers with elevated copper levels described above [30]. CD147 plays very important roles in angiogenesis, proliferation and metastasis of many cancers and is an effective diagnostic marker and therapeutic target [30-32], especially in HCC treatment using CD147directed monoclonal antibodies [33]. The biological functions of CD147 involved in cancer progression are largely attributed to its ability to stimulate the secretion of extracellular matrix metalloproteinases (MMPs, a family of zinc-dependent endopeptidases) in cancer cell themselves and from neighboring fibroblasts [34]. MMP-mediated extracellular matrix degradation greatly contributes to cancer cell invasion and metastasis [35]. Although the MMPinducing activity of CD147 is suggested to be dependent on its self-association [34], the reported homophilic interaction interfaces are controversial and little is known about the regulatory mechanisms involved in this process [36-38]. Therefore, the molecular mechanism of CD147 in stimulating the secretion of MMPs has not been fully elucidated.

Here we establish a direct link for the functions of extracellular $\mathrm{Cu}^{2+}$ and $\mathrm{CD} 147$ by demonstrating that $\mathrm{Cu}^{2+}$ plays a signaling role on $\mathrm{HCC}$ cells through mediating the self-association of its cell surface receptor CD147, which in turn promotes MMPs secretion and enhances the invasiveness of HCC cells.

\section{RESULTS}

\section{Extracellular $\mathrm{Cu}^{2+}$ up-regulates MMP-2 and MMP-14 expression in HCC cells through activating PI3K/Akt signaling pathway}

The copper chelator tetrathiomolybdate (TM) was shown to inhibit tumor cell metastasis through downregulating MMPs levels [39]. We used quantitative PCR with reverse transcription (qRT-PCR) to verify whether copper is able to directly stimulate MMPs expression in cancer cells. The mRNA levels of both MMP-2 and MMP-14 in human hepatocellular carcinoma (HCC) cell SMMC-7721 were up-regulated by $\mathrm{Cu}^{2+}$ in a concentration dependent manner, whereas the mRNA levels for other tested MMPs (MMP-1, MMP-3 and MMP-9) were not changed when treated with up to $40 \mu \mathrm{M} \mathrm{Cu}^{2+}$ (Figure 1A and 1B, Supplementary Figure 1). As shown in Figure 1, MMP-2 mRNA level reaches a maximum at $30 \mu \mathrm{M}$ $\mathrm{Cu}^{2+}$, while the maximum for MMP-14 is at $20 \mu \mathrm{M} \mathrm{Cu}^{2+}$. The membrane-anchored MMP-14 also functions as the activator of secreted MMP-2 from its inactive zymogen; and both MMP-2 and MMP-14 promotes cancer cell invasion and metastasis $[35,40,41]$, implicating that $\mathrm{Cu}^{2+}$ may modulate the metastatic properties of HCC cells by directly up-regulating MMP-2 and MMP-14 expression.

Copper has been shown to strongly activate the phosphoinositide 3 kinase (PI3K)/Akt signaling both in normal and cancer cells $[42,43]$. Activation of PI3K/ Akt signaling was also reported to be involved in MMP up-regulation in $\mathrm{HCC}$ cells [44]. We thus examined whether the MMP-inducing activity of copper is dependent on PI3K/Akt signaling pathway. The amount of phosphorylated Akt (p-Akt) in SMMC-7721 cells was significantly increased by $\mathrm{Cu}^{2+}$ at a concentration of $5 \mu \mathrm{M}$, which was further augmented by $\mathrm{Cu}^{2+}$ with concentrations higher than $20 \mu \mathrm{M}$ (Figure 1C). Interestingly, $\mathrm{Cu}^{2+}$ stimulated expressions of MMP-2 and MMP-14 were abolished when the phosphorylation of Akt was inhibited by the specific PI3K inhibitor LY294002 (Figure 1D and $1 \mathrm{E})$. These results suggest that activation of PI3K/Akt signaling is essential for $\mathrm{Cu}^{2+}$ to up-regulate MMP-2 and MMP-14 expression in HCC cells.

We next investigated whether decreasing the influx of copper affects its stimulation of MMPs expression in SMMC-7721 cells. Knockdown of CTR1, the key transporter for cellular copper uptake, had no effect on the copper-induced elevation of MMP-2 and MMP-14 mRNA levels (Figure 2A-2C), even though the intracellular monovalent copper $\left(\mathrm{Cu}^{+}\right)$concentration was significantly decreased (Figure 2D). Therefore, it is the extracellular divalent $\mathrm{Cu}^{2+}$, rather than the intracellular monovalent $\mathrm{Cu}^{+}$, that up-regulates MMP-2 and MMP-14 expression in HCC cells. 


\section{CD147 is indispensible for $\mathrm{Cu}^{2+}$-stimulated up- regulation of MMPs}

As CD147 is well-characterized as an inducer of MMPs [31, 32], we thus investigated whether CD147 is involved in MMPs expression stimulated by extracellular $\mathrm{Cu}^{2+}$. It was found that the $\mathrm{Cu}^{2+}$-induced up-regulation of MMP-2 and MMP-14 mRNA levels were markedly decreased when the expression of CD147 was suppressed by short hairpin RNA (shCD147) (Figure 3A-3C). Immunoblot showed that knockdown of CD147 also impaired the elevated MMP-14 protein level by $\mathrm{Cu}^{2+}$ treatment (Figure 3D). Thus, the up-regulation of MMP-2 and MMP-14 expression in $\mathrm{HCC}$ cells by extracellular $\mathrm{Cu}^{2+}$ is CD147 dependent.

Over-expressed CD147 on cancer cell surface strongly activate MMPs production from adjacent fibroblasts [34]. We asked whether $\mathrm{Cu}^{2+}$ also plays a stimulatory role in this process. Gelatin zymography showed that $\mathrm{Cu}^{2+}$ treatment stimulated MMP-2 secretion
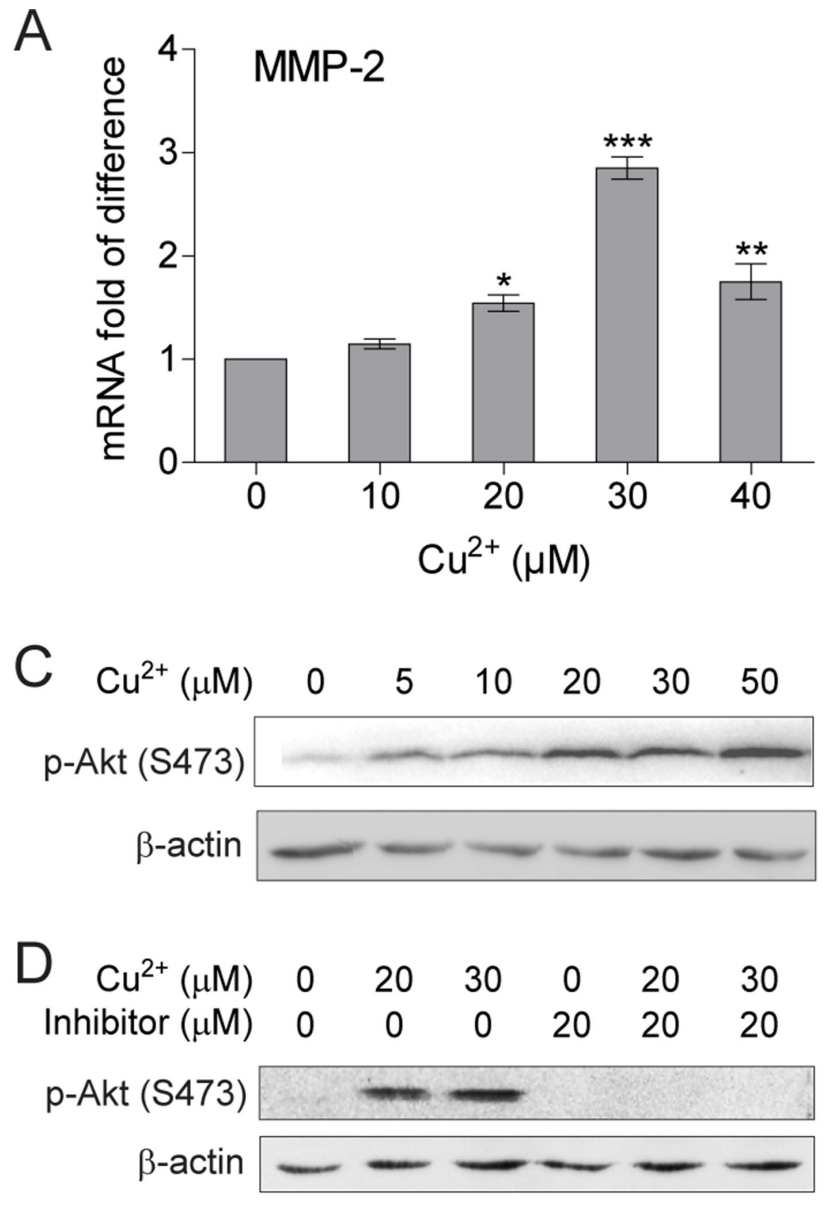

from fibroblasts co-cultured with SMMC-7721 cells, which was notably impaired by the knockdown of CD147 (Figure 3E). MMP-2 expression was not affected by $\mathrm{Cu}^{2+}$ treatment when fibroblasts were cultured alone (Supplementary Figure 2). These results suggest that $\mathrm{Cu}^{2+}$ increases the capability of HCC cells to induce MMP2 expression from neighboring fibroblasts in a CD147 dependent manner.

However, $\mathrm{Cu}^{2+}$ treatment did not alter the expression level of CD147 in SMMC-7721 cells (Supplementary Figure 3), suggesting that the up-regulation of MMPs expression in HCC cells or neighboring fibroblasts is not due to higher expression of CD147.

\section{$\mathrm{Cu}^{2+}$ directly interacts with the extracellular membrane-proximal domain of CD147}

We then investigated whether the effect of $\mathrm{Cu}^{2+}$ is due to a direct interaction with CD147, and carried out
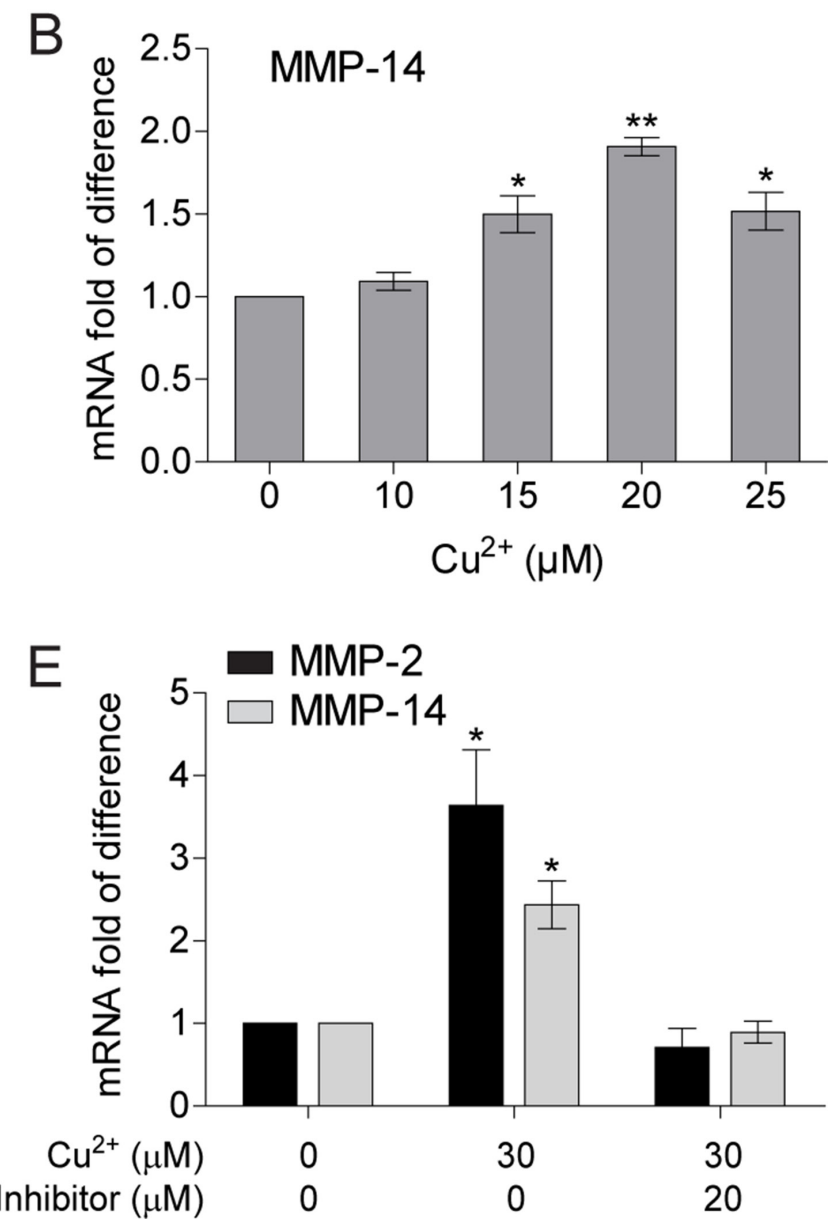

Figure 1: $\mathrm{Cu}^{2+}$ stimulates MMP-2 and MMP-14 expression in HCC cells through activating PI3K/Akt signaling pathway. (A, B) qRT-PCR analysis of MMP-2 (A) and MMP-14 (B) in SMMC-7721 cells treated with different concentrations of $\mathrm{Cu}^{2+}$ $(n=3$, mean \pm SEM, one way ANOVA). (C) Immublot analysis of the p-Akt levels in SMMC-7721 cells treated with different concentrations of $\mathrm{Cu}^{2+}$. (D) PI3K inhibitor (LY294002) reduces the $\mathrm{Cu}^{2+}$-augmented p-Akt levels in SMMC-7721 cells. (E) PI3K inhibitor abolishes $\mathrm{Cu}^{2+}-$ induced mRNA elevation of MMP-2 and MMP-14 ( $n=3$, mean \pm SEM, one way ANOVA). $* P<0.05,{ }^{* *} P<0.01$ and $* * * P<0.001$. Gel images in panel $\mathrm{C}$ and $\mathrm{D}$ are representative of at least two technical replicates. 
in vitro NMR titration experiment with the ectodomain of CD147 (CD147 ${ }^{\mathrm{ECT}}$, residues 22-205). Upon titrating ${ }^{15} \mathrm{~N}$-labeled CD147 ${ }^{\mathrm{ECT}}$ with $\mathrm{Cu}^{2+}$, $\mathrm{NH}$ signal intensities of almost all residues are gradually weakened, which could be mostly reversed with the addition of TM or EDTA (Figure 4A and 4B, Supplementary Figure 4A-4C). In the presence of 2-fold excess of $\mathrm{Cu}^{2+}$, there is $\sim 2$.6-fold $\mathrm{NH}$ signal intensity decrease relatively uniformly for residues from the membrane-distal domain (residues 22-101), and it is an average of 4.1-fold reduction for residues from the membrane-proximal domain (residues 106-205) with some NH signals showing much greater intensity decreases. NH signals of residues Val107, Lys111, His115-Leu124, His170-Asn173, Met176, Ser204 and His205 were missing, while residues His102, Glu155, Ser162, Glu168, Gln195 and Arg203 had over 6-fold NH signal intensity reduction (Figure 4A and 4B). Almost all these residues are spatially clustered on one side of the membrane-proximal domain of CD147 ${ }^{\mathrm{ECT}}$ (Figure 4F). The drop of NH signal intensity was presumably due to the paramagnetic relaxation enhancement (PRE) effect of $\mathrm{Cu}^{2+}$, as $\mathrm{Cu}^{2+}$ can cause enhanced relaxation of spins in proximity. This suggests a direct interaction between $\mathrm{Cu}^{2+}$ and $\mathrm{CD} 147^{\mathrm{ECT}}$.

Based on the NMR titration result, targeted mutagenesis revealed that combinations of H115A, H170A and $\mathrm{H} 205 \mathrm{~A}$ mutations progressively decreased the $\mathrm{NH}$ signal responses of $\mathrm{CD} 147^{\mathrm{ECT}}$ to $\mathrm{Cu}^{2+}$, while the CD147 ${ }^{\mathrm{ECT}}$ variant with triple mutations (3HA) almost abolishes the response of NMR signals to $\mathrm{Cu}^{2+}$ (Figure 4B and 4C, Supplementary Figure 4A and 4D). These results suggest that all three histidine residues should be involved in $\mathrm{Cu}^{2+}$ binding, and there may be multiple $\mathrm{Cu}^{2+}$ binding sites on the membrane-proximal domain of CD147 as these three residues are not near each other on protein tertiary structure (Figure 4F).
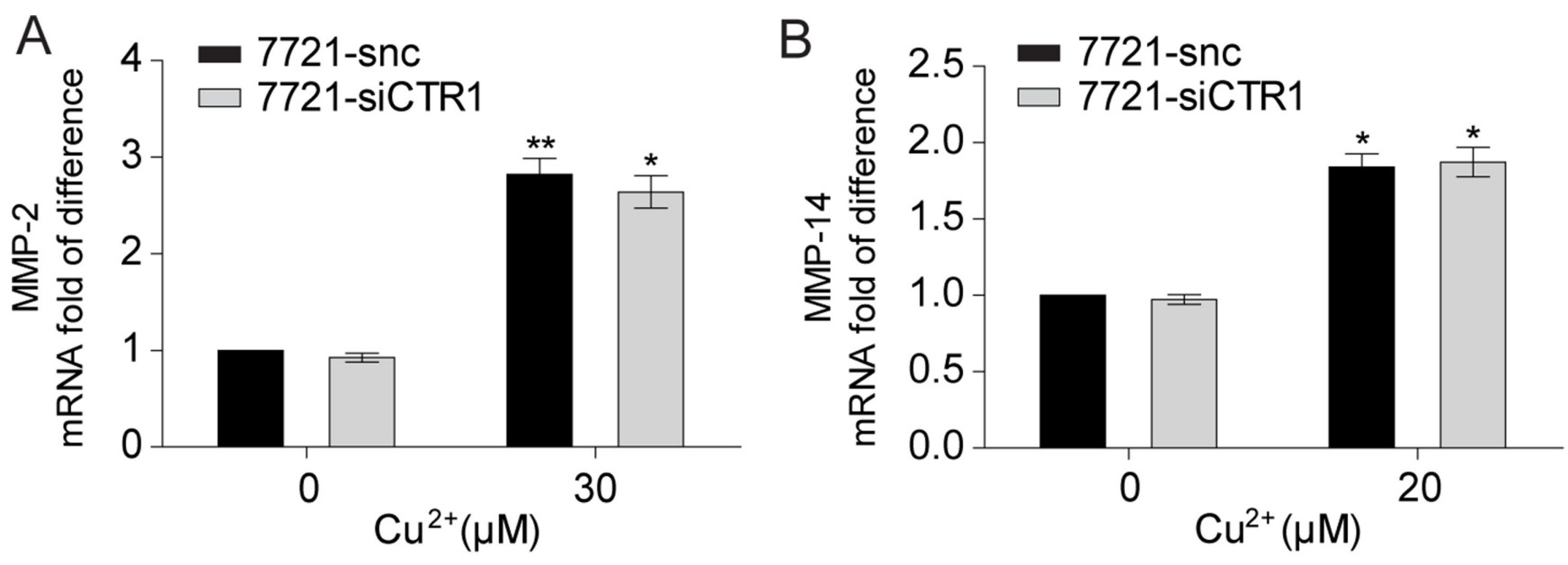

C
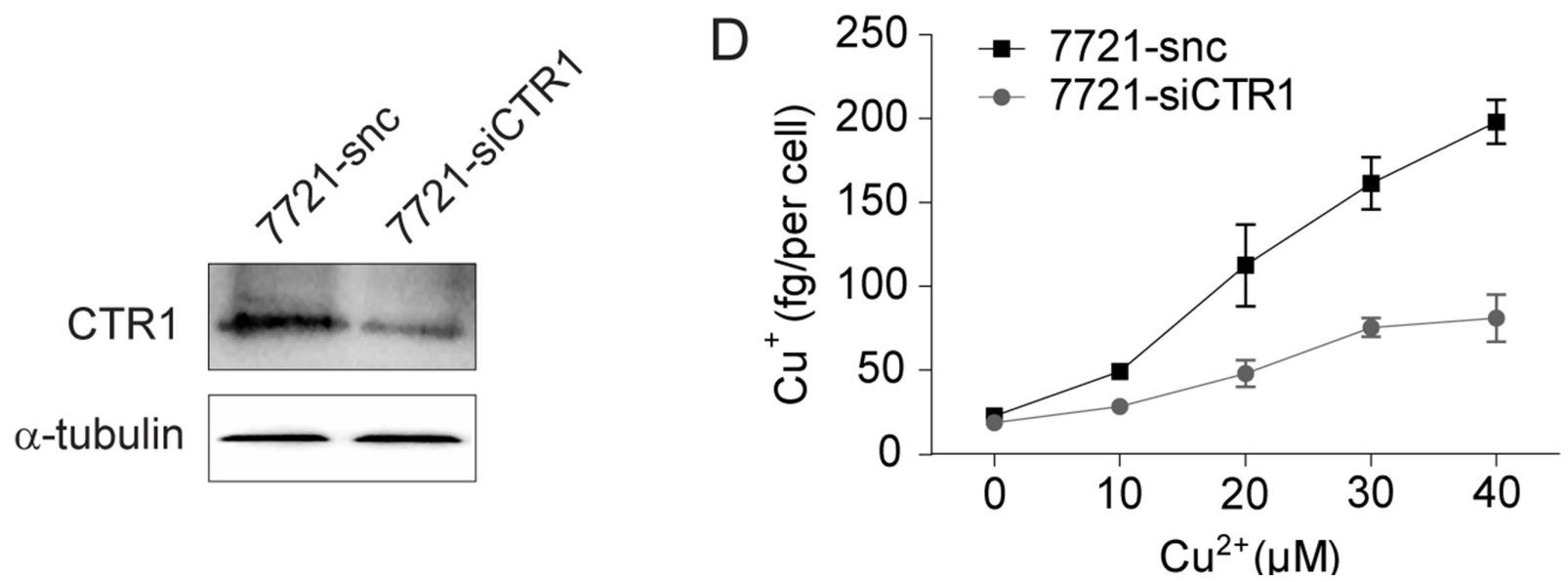

Figure 2: Intracellular uptake is not required for copper to up-regulate MMP-2 and MMP-14 expression. (A, B) qRTPCR analysis of MMP-2 (A) and MMP-14 (B) in SMMC-7721 cells with or without $\mathrm{Cu}^{2+}$ treatment $(n=3$, mean $\pm \mathrm{SEM}, t$-test). Cells were transfected with ctr1-specific siRNA (7721-siCTR1) or control siRNA (7721-snc). (C) The copper intracellular uptake was significantly impaired in 7721-siCTR1 cells compared with 7721-snc cells as assessed by atomic absorption spectroscopy $(n=2$, mean \pm SEM). (D) Immunoblot analysis of CTR1 in 7721-siCTR1 and 7721-snc cells. $* P<0.05$ and $* * P<0.01$. Gel images in panel D are representative of at least two technical replicates. 


\section{$\mathrm{Cu}^{2+}$ can mediate self-association of CD147}

The triple mutations should not influence the PRE effect of $\mathrm{Cu}^{2+}$ on $\mathrm{NH}$ signals from the membrane-distal domain of CD147, since all the three histidine residues are located on the membrane-proximal domain. However, the overall intensity drop caused by $\mathrm{Cu}^{2+}$ for $\mathrm{NH}$ signals of the membrane-distal domain was also significantly rescued by the 3HA mutations (Figure 4B and 4C), suggesting that the signal reduction caused by $\mathrm{Cu}^{2+}$ cannot be simply explained by the PRE effect. These observations prompted the speculation that $\mathrm{Cu}^{2+}$ can induce self-association of CD147, which results in slower rotational motion of CD147 in solution and thus faster relaxation of NMR signal.

Chemical cross-linking showed that either WT CD147 ${ }^{\mathrm{ECT}}$ or $3 \mathrm{HA}$ mutant cannot be cross-linked without $\mathrm{Cu}^{2+}$, consistent with that $\mathrm{CD} 147$ by itself is essentially a monomer in solution [26, 45]. However, in the presence of $\mathrm{Cu}^{2+}$, strong protein bands corresponding to $\mathrm{CD} 147^{\mathrm{ECT}}$ dimer and even higher order oligomers could be detected, and the amounts of cross-linked dimer and oligomers were positively correlated with the $\mathrm{Cu}^{2+}$ concentration (Figure 4D). The amounts of cross-linked dimer or oligomers were much less for 3HA mutant in the presence of $\mathrm{Cu}^{2+}$ compared to those of WT CD147 ${ }^{\mathrm{ECT}}$. Surface plasma resonance (SPR) further confirmed the $\mathrm{Cu}^{2+}$-induced self-association of CD147. No homophilic interaction among WT or $3 \mathrm{HA}$ mutant $\mathrm{CD} 147^{\mathrm{ECT}}$ proteins was observed without $\mathrm{Cu}^{2+}$. However, sensorgrams with clear association and dissociation processes were obtained when $\mathrm{Cu}^{2+}$ was present in the analyte (Figure 4E). As for 3HA mutant, the binding was dramatically reduced compared to that of WT CD147 $7^{\mathrm{ECT}}$, in the presence of $\mathrm{Cu}^{2+}$. These results indicate that $\mathrm{Cu}^{2+}$ does induce selfassociation of WT CD147, which is significantly impaired by the 3HA mutations.
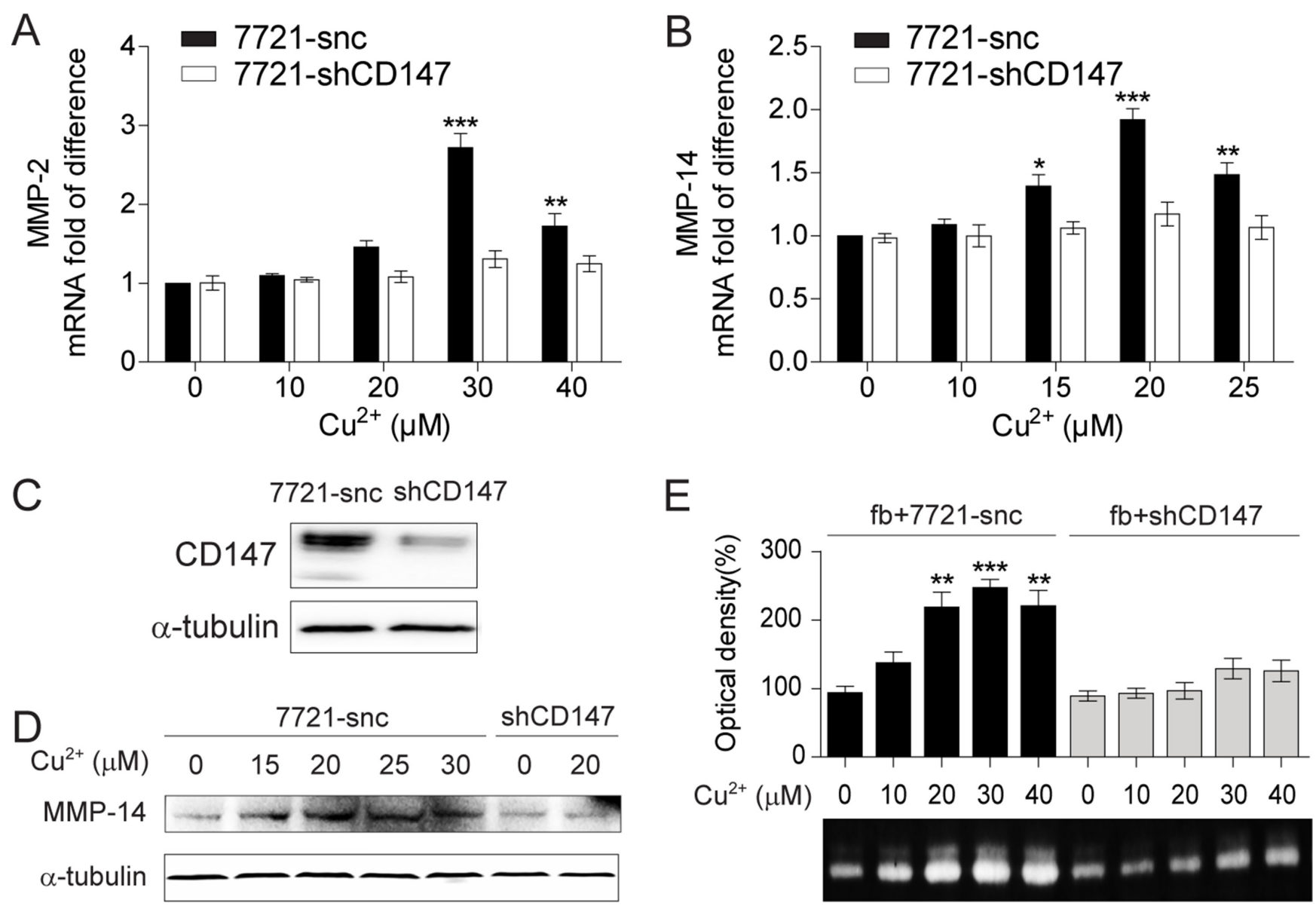

Figure 3: The MMP-inducing activity of $\mathrm{Cu}^{2+}$ is CD147 dependent. (A, B) qRT-PCR analysis of MMP-2 (A) and MMP-14 (B) in SMMC-7721 cells treated with different concentrations of $\mathrm{Cu}^{2+}(n=3$, mean $\pm \mathrm{SEM}$, one way ANOVA). Cells were transfected with $c d 147-$ specific shRNA (7721-shCD147) or control shRNA (7721-snc). (C) The expression of CD147 is knocked down in 7721-shCD147 but not 7721 -snc cells. (D) Immunoblot analysis of MMP-14 in 7721-snc or 7721-shCD147 cells treated with different concentrations of $\mathrm{Cu}^{2+}$. $(\mathbf{E})$ The levels of MMP-2 secreted from fibroblasts (fb) co-cultured with 7721-snc or 7721-shCD147 cells as determined by gelatin zymography $\left(n=3\right.$, mean \pm SEM, one way ANOVA). ${ }^{*} P<0.05,{ }^{*} P<0.01$ and $* * * P<0.001$. Gel images in panel $\mathrm{C}$ and $\mathrm{D}$ are representative of at least two technical replicates. 


\section{$\mathrm{Cu}^{2+}$-mediated CD147 self-association up- regulates MMPs expression}

To investigate the role of $\mathrm{Cu}^{2+}$-induced CD147 self-association, WT or 3HA mutant CD147 was stably transfected into $c d 147^{-1-}$ SMMC-7721 (K7721) cells. The resulting cell lines with WT CD147 (K7721-WT) or 3HA mutant (K7721-3HA) expressed on cell surfaces had similar expression levels to that of SMMC-7721 cells (Supplementary Figure 5). It is interesting to notice that all four types of cells (SMMC-7721, K7721, K7721-WT and K7721-3HA) showed similar low expression levels for MMP-2 and MMP-14 (Figure 5A and 5B), without the addition of $\mathrm{Cu}^{2+}$, suggesting that $\mathrm{Cu}^{2+}$ is required for CD147 to induce MMPs production.

Distinct from those of SMMC-7721 cells, MMP-14 mRNA level was not changed and that of MMP-2 was even reduced in $\mathrm{K} 7721$ cells when treated with $\mathrm{Cu}^{2+}$, which can be fully rescued by the expression of WT CD147 but not the 3HA mutant (Figure 5A and 5B). Consistently, $\mathrm{Cu}^{2+}$ was unable to activate the PI3K/Akt signaling in K7721 cells (Figure 5C), and the expression of WT CD147 rather than the 3HA mutant can restore the $\mathrm{Cu}^{2+}$ augmented p-Akt level (Figure 5D). Gelatin zymography also showed that MMP-2 production was not significantly changed in $\mathrm{Cu}^{2+}$ treated fibroblasts co-cultured with K7721-3HA cells, while that for K7721-WT cells was increased by 2.2-fold with $30 \mu \mathrm{M} \mathrm{Cu}^{2+}$ treatment (Figure 5E). As the 3HA mutations nearly abolish the binding of $\mathrm{Cu}^{2+}$ to $\mathrm{CD} 147^{\mathrm{ECT}}$ and impair the $\mathrm{Cu}^{2+}$-induced oligomerization of CD147 ${ }^{\mathrm{ECT}}$, these results suggest that mediating CD147 self-association is the underlying molecular mechanism for $\mathrm{Cu}^{2+}$ to activate the PI3K/Akt signaling and stimulate MMP-2 and MMP-14 expression.

To further test whether the intracellular domain of CD147 is involved in the signal transduction for
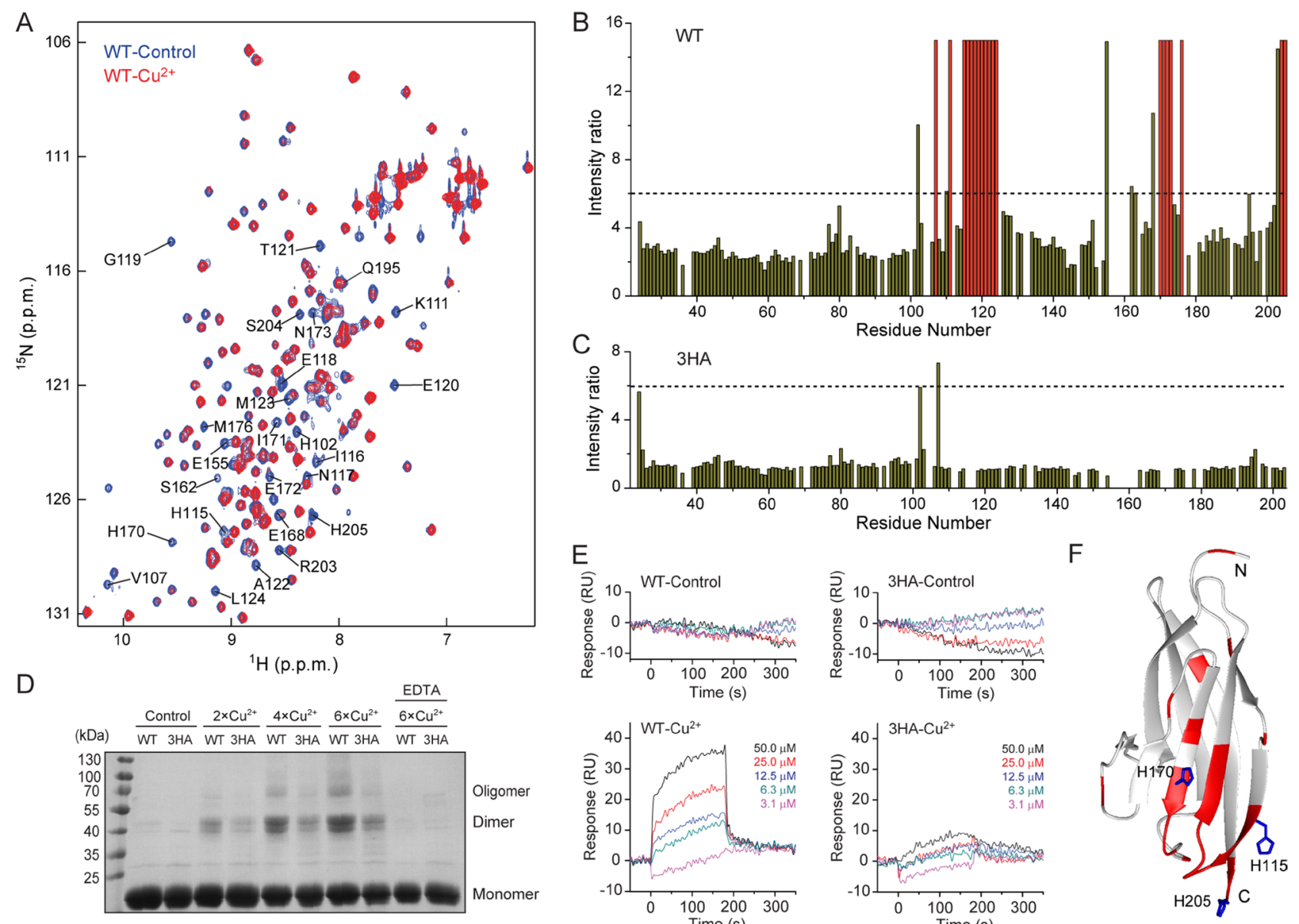

Figure 4: $\mathrm{Cu}^{2+}$ directly interacts with and mediates self-association of the membrane-proximal domain of $\mathrm{CD147}$. (A) Overlay of $2 \mathrm{D}{ }^{1} \mathrm{H}-{ }^{15} \mathrm{~N}$ HSQC spectra of WT-CD147 ${ }^{\mathrm{ECT}}$ with (red) or without (blue) 2-fold excess of $\mathrm{Cu}^{2+}$. Residues displaying significant $\mathrm{NH}$ signal intensity reduction upon $\mathrm{Cu}^{2+}$ titration are labeled. $(\mathbf{B}, \mathbf{C})$ Plot of $\mathrm{NH}$ signal intensity ratio for wild-type CD147 ${ }^{\mathrm{ECT}}$ (B) or the 3HA mutant (C) in the absence and in the presence of 2-fold excess of $\mathrm{Cu}^{2+}$. Dashed lines indicate the ratio of 6 . Residues with $\mathrm{NH}$ signals disappeared upon $\mathrm{Cu}^{2+}$ titration are depicted in red. (D) Cross-linking analysis of WT-CD147 ${ }^{\mathrm{ECT}}$ and the $3 \mathrm{HA}$ mutant with different concentrations of $\mathrm{Cu}^{2+}$. (E) SPR analysis of the homophilic interactions of WT-CD147 ${ }^{\mathrm{ECT}}$ or the 3HA mutant with or without Cu${ }^{2+}$. RU, response unit. (F) Residues with missing NH signals or the signal intensity reduction ratio larger than 6 upon $\mathrm{Cu}^{2+}$ titration are mapped on the structure of the membrane-proximal domain of CD147. Side chains of His115, His170 and His205 are shown by sticks. 
extracellular $\mathrm{Cu}^{2+}$, a $\mathrm{K} 7721$ cell line that expressed a truncated version CD147 (K7721- $\Delta \mathrm{C})$ with its intracellular domain (residues 229-269) deleted was constructed. It was found that extracellular $\mathrm{Cu}^{2+}$ was still able to up-regulate MMP-2 and MMP-14 expression in K7721- $\Delta \mathrm{C}$ cells (Supplementary Figure 6), suggesting that the intracellular domain of CD147 is not required for the signal transduction of this process. It is possible that the signal of $\mathrm{Cu}^{2+}$-mediated CD147 oligomerization is transduced into the cell through interactions with other cell surface proteins, yet to be identified.
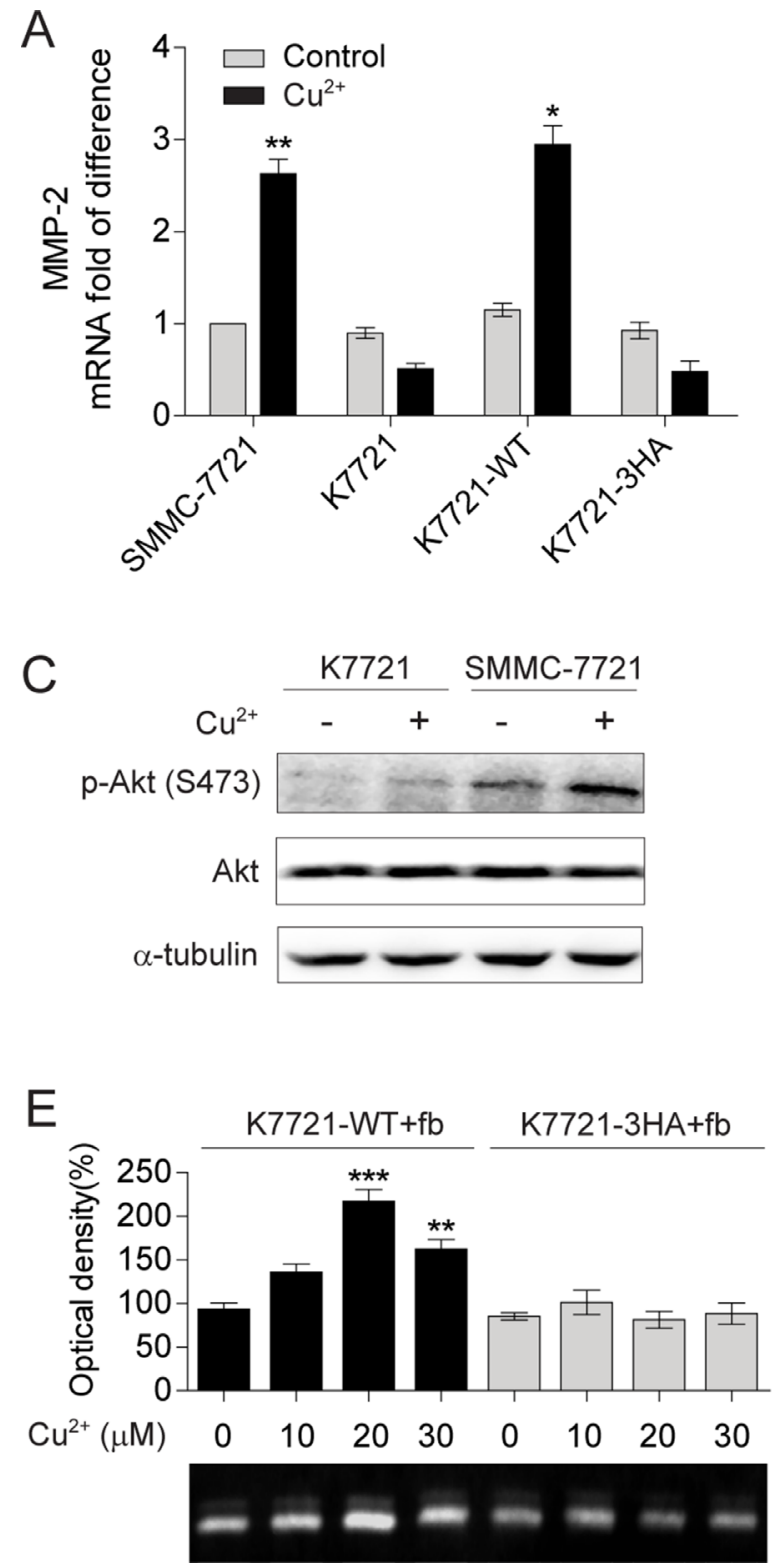

\section{$\mathrm{Cu}^{2+}$-mediated CD147 self-association accelerates HCC cell invasion}

CD147 and MMPs, especially MMP-2 and MMP14 , are frequently involved in tumor cell metastasis $[30,35]$. Meanwhile, the copper chelator TM was reported to significantly decrease tumor cell invasiveness [39]. To assess whether self-association of CD147 mediated by $\mathrm{Cu}^{2+}$ can modulate the invasion ability of tumor cells, transwell invasion assays were performed. It was found that the invasiveness of K7721 cells was dramatically
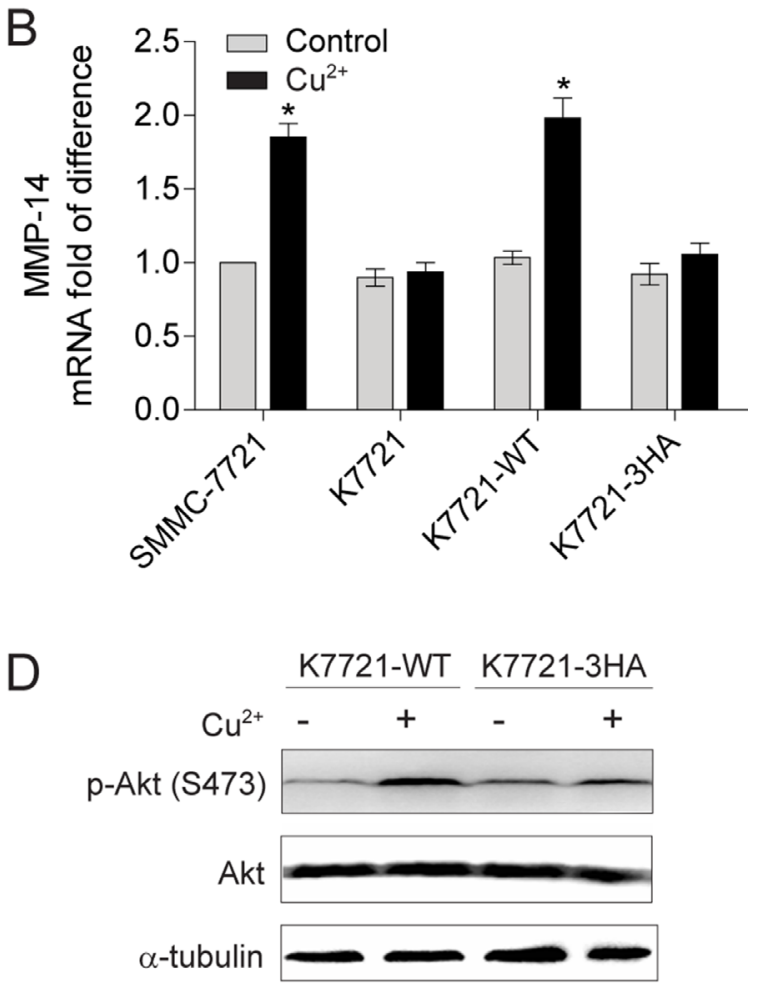

Figure 5: Self-association of CD147 mediated by $\mathrm{Cu}^{2+}$ up-regulates MMP-2 and MMP-14 expression. (A, B) qRT-PCR analysis of MMP-2 (A) and MMP-14 (B) in SMMC-7721, K7721, K7721-WT and K7721-3HA cells with or without Cu ${ }^{2+}$ treatment (30 $\mu \mathrm{M}$ for MMP-2 detection and $20 \mu \mathrm{M}$ for MMP-14 detection, $n=3$, mean $\pm \mathrm{SEM}, t$-test). (C, D) Immublot analysis of the p-Akt levels in SMMC-7721, K7721 cells (C) and in K7721-WT, K7721-3HA cells (D) with or without $10 \mu \mathrm{M} \mathrm{Cu}^{2+}$ treatment. (E) Gelatin zymogrphy analysis of MMP-2 secretion from fibroblasts (fb) co-cultured with K7721-WT and K7721-3HA cells treated with different concentrations of $\mathrm{Cu}^{2+}(n=3$, mean $\pm \mathrm{SEM}$, one way ANOVA). Gel images in panel $\mathrm{C}$ and $\mathrm{D}$ are representative of at least two technical replicates. 
decreased compared with SMMC-7721 cells (Figure 6A). The copper chelator TM inhibited the invasion ability of SMMC-7721 cells, while it had no effect on K7721 cells (Figure 6A). Moreover, the expression of WT CD147 but not the copper-binding deficient $3 \mathrm{HA}$ mutant can restore the reduced invasiveness of K7721 cells due to CD147 knockout (Figure 6B). These results indicate that self-association of CD147 enhances the invasiveness of SMMC-7721 cells, which can be abolished either by the copper chelator TM or by the 3 HA mutations. Thus, $\mathrm{Cu}^{2+}$ mediated CD147 self-association may play an important role in $\mathrm{HCC}$ cell metastasis.

\section{DISCUSSION}

Recent studies revealed that CD147 also functions as the receptor for multiple protein factors, such as chemoattractant CyPA [24, 46, 47], malaria invasion
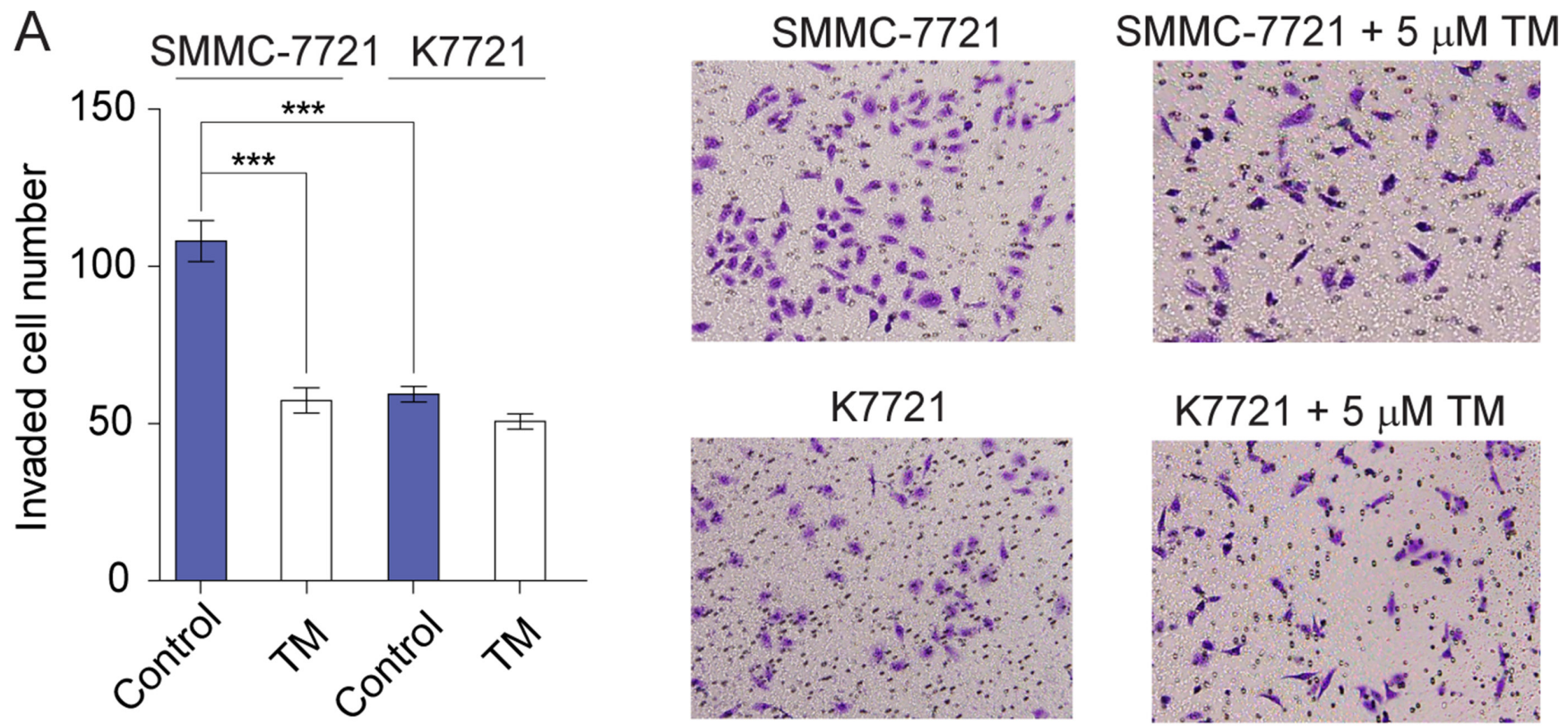

\section{K7721}

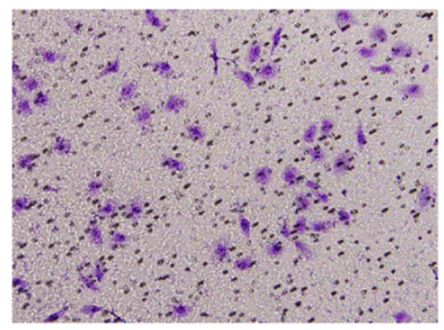

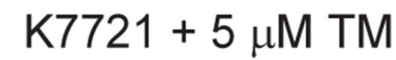

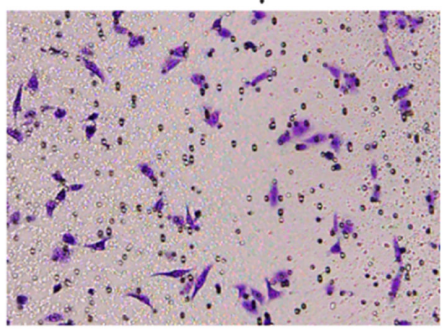

B

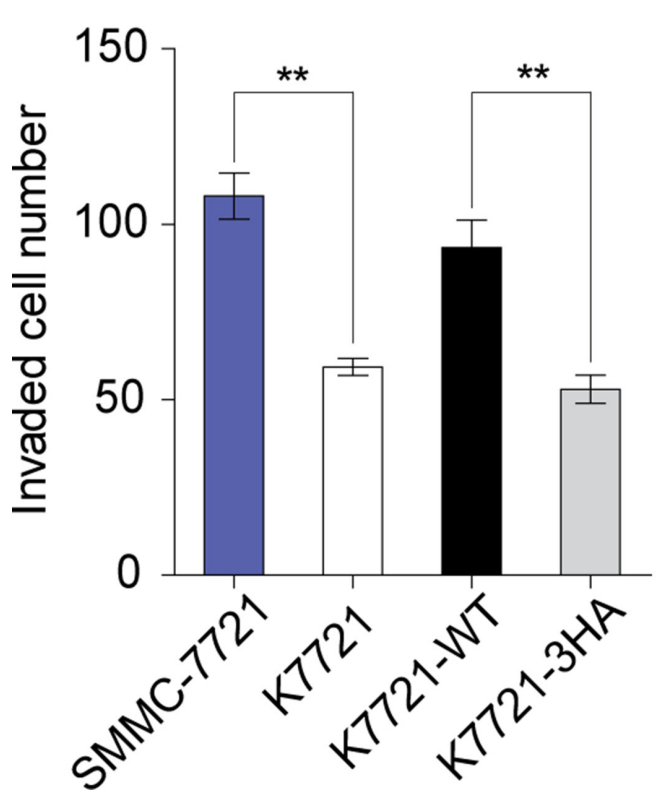

SMMC-7721

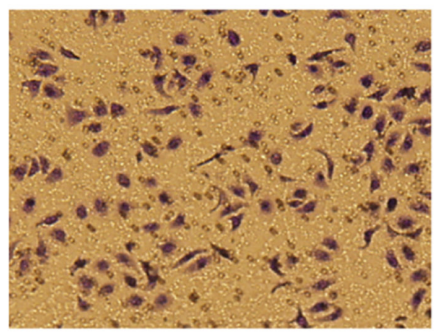

K7721-WT

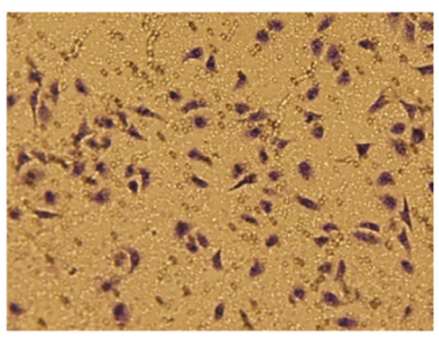

K7721

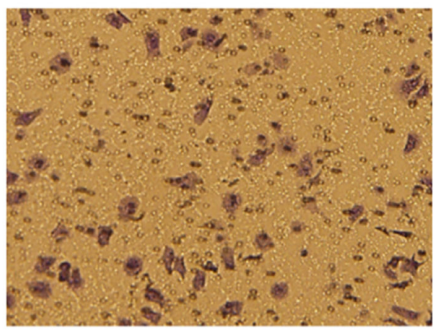

K7721-3HA

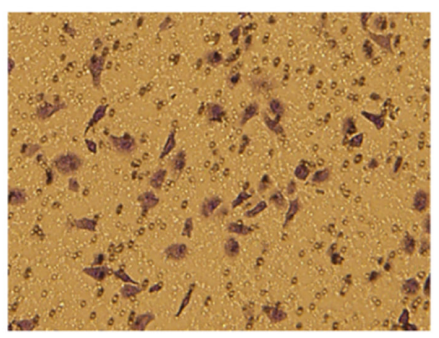

Figure 6: $\mathrm{Cu}^{2+}$-mediated CD147 self-association enhances HCC cells invasiveness. (A) In vitro invasion assay of SMMC7721 and K7721 cells with or without $5 \mu \mathrm{M}$ TM treatment ( $n=3$, mean \pm SEM, one way ANOVA). (B) Invasion assay of SMMC-7721, K7721, K7721-WT and K7721-3HA cells ( $n=3$, mean \pm SEM, one way ANOVA). $* * P<0.01, * * * P<0.001$. 
protein RH5 [25, 26], meningococcal pilus components PilE and PilV [27], and Rod-derived cone viability factor (RdCVF) [28]. Here, we have demonstrated that CD147 is a bona fide signaling receptor for extracellular $\mathrm{Cu}^{2+}$ in cancer cells: the self-association of CD147 mediated by extracellular $\mathrm{Cu}^{2+}$ signals the up-regulation of MMP-2 and MMP-14 in HCC cells through activating PI3K/Akt pathway, stimulates MMP-2 production from neighboring fibroblasts and promotes $\mathrm{HCC}$ cell invasion. Without $\mathrm{CD} 147$, extracellular $\mathrm{Cu}^{2+}$ did not show a stimulating role on MMP-2 and MMP-14 expression, as well as PI3K/ Akt signaling. Consistently, $\mathrm{Cu}^{2+}$ only has a marginal effect on MMPs induction when CD147 expression level is knockdown with shRNA. Meanwhile, without extracellular $\mathrm{Cu}^{2+}$, whether the expression of CD147 or not does not affect the expression of MMP-2 and MMP14 , neither the invasiveness of HCC cells. It may provide an explanation for a recent report that claims CD147 is unable to induce the production of MMPs [48]. Therefore, the MMPs-inducing activities of CD147 and $\mathrm{Cu}^{2+}$ are interdependent, and the roles of copper and CD147 in cancer progression are unprecedentedly linked together.

As an essential trace metal for life, copper should be involved in different aspects of cancer, and emerging evidences suggest that copper is a key regulator of many cell signaling pathways [49]. While most previous studies were focused on the intracellular roles of copper $[1,18-20]$, the biological roles of extracellular $\mathrm{Cu}^{2+}$ in cancer have been largely ignored. Although it is well established that most of serum copper is incorporated into ceruloplasmin (CP), the finding of intracellular copper translocation across cell membrane from recent studies make it possible that transient high concentration of free copper outside the plasma membrane may exist physiologically $[3,22,23]$. Our results clearly demonstrate that extracellular $\mathrm{Cu}^{2+}$ plays a direct signaling role through its cell surface receptor CD147 in HCC cells. We found that copper can also up-regulate MMP-2 and MMP14 expression in human hepatocellular carcinoma cell HUH-7 and human pancreatic cancer cell MIA PaCa-2 (Supplementary Figure 7). It is thus very likely that the signaling role of extracellular $\mathrm{Cu}^{2+}$ may also apply to other type of cancer cells with high CD147 expression level. As copper, CD147, MMP-2 and MMP-14 are all implicated to promote the metastasis of cancer $[3,32,35]$, our study sheds light upon their functional mechanisms and relationship in cancer progression. Therefore, targeting the interaction between $\mathrm{Cu}^{2+}$ and $\mathrm{CD} 147$ or the $\mathrm{Cu}^{2+}$-induced self-association of CD147 may provide an alternative therapeutic strategy to anti-cancer drug development. Meanwhile, as we have found that TM has no effect on the invasiveness of cancer cells without CD147, it may provide a strategy of precision medicine for patient selection in the design of future clinic trials for copperlowering anti-cancer therapy.

\section{MATERIALS AND METHODS}

\section{Cell culture}

Human hepatocellular carcinoma cells SMMC7721 and human fibroblast cells were obtained from the Institute of Cell Biology, Academic Sinica (Shanghai, China). Human hepatocellular carcinoma cells HuH-7 were purchased from the Japanese Collection of Research Bioresources Cell Bank (JCRB). Human pancreatic cancer cells MIA PaCa-2 were purchased from the American Type Culture Collection (ATCC). K7721 (cd147-1SMMC-7721), SMMC-7721 shCD147, SMMC-7721 snc, MIA PaCa-2 shCD147 and MIA PaCa-2 snc cells were developed and preserved in our laboratory.

SMMC-7721, SMMC-7721 shCD147, SMMC7721 snc, K7721 cells and fibroblasts were cultured in RPMI 1640 medium (Gibco, New York, USA). HuH-7, MIA PaCa-2, MIA PaCa-2 shCD147 and MIA PaCa-2 snc cells were cultured in DMEM medium (Gibco, New York, USA). Both media were supplemented with $10 \%$ FBS and $1 \%$ penicillin/streptomycin and all cells were cultured at $37^{\circ} \mathrm{C}$ with $5 \% \mathrm{CO}_{2}$.

\section{RNA interference}

siRNAs were transfected into SMMC-7721 cells using Lipofectamine 2000 reagent according to the manufacturer's instructions (Invitrogen, Carlsbad, CA). siRNAs for human CTR1 and silencer negative control siRNA (sncRNA) were purchased from Santa Cruz (Dallas, Texas).

\section{Plasmids transfection}

pcDNA3.1 encoding full-length WT-CD147 or 3HA mutant was transfected into K7721 cells using Lipofectamine 2000 reagent according to the manufacturer's instructions (Invitrogen, Carlsbad, CA). After G418 selection, the cells were sorted by flow cell sorter.

\section{qRT-PCR}

SMMC- 7721 or other Cells $\left(5 \times 10^{5}\right)$ were seeded and incubated in 6-well plates until the cell density was $80 \%$. Cells were rinsed three times with serum-free medium and incubated in serum-free medium for $24 \mathrm{~h}$. Then, cells were washed three times again and serum-free medium with different concentrations of $\mathrm{Cu}^{2+}$ was added for further incubation of $24 \mathrm{~h}$. Total RNA was extracted using a total RNA extraction Kit (Omega, Norcross, GA) and reversely transcribed with a ReverTra Ace-a kit (Toyobo, Osaka, Japan). Real-time RT-PCR was performed using the SYBR Premix EX Taq II (Takara, Shiga, Japan) with the 
sequence detection system Stratagene Mx3005P (Agilent Technologies, Frankfurt am Main, Germany). The primers were synthesized by BGI (Beijing, China) and are listed in Supplementary Table 1. GAPDH was used to normalize the RNA inputs, which yield $\Delta \mathrm{Ct}$ values. All the mRNA fold of difference values $\left(2^{\wedge}-\Delta \Delta C t\right)$ were relative to the control group (SMMC-7721 cells without $\mathrm{Cu} 2+$ treatment), while $\Delta \Delta \mathrm{Ct}$ was calculated by subtracting $\Delta \mathrm{Ct}$ value of the control group. Errors were assessed for fold of difference values from 3 independent experiments.

\section{Proliferation assay}

SMMC-7721 cells $\left(5 \times 10^{4}\right)$ were seeded in 96-well plates and incubated overnight. Cells were rinsed three times with serum-free medium and incubated in serumfree medium for $24 \mathrm{~h}$. Then, cells were washed three times again and serum-free medium with different concentrations of $\mathrm{Cu}^{2+}$ was added for further incubation of $24 \mathrm{~h}$. $10 \mu \mathrm{L} /$ well WST-1 was added and incubated for $2 \mathrm{~h}$. The absorbance of the dye with a wavelength of $450 \mathrm{~nm}$ was then detected by a scanning multiwell spectrophotometer (Bio-Rad, Hercules, CA). Culture medium with WST-1 was used as blank control. Three different experiments were performed for each experimental condition.

\section{Atomic absorption spectroscopy}

SMMC-7721 cells transfected with siRNA for CTR1 or sncRNA were treated with different concentrations of $\mathrm{Cu}^{2+}$ for $24 \mathrm{~h}$ and then trypsinized, rinsed three times with PBS. Cells were harvested and digested with $30 \mu \mathrm{L} 65 \%$ nitric acid at $60^{\circ} \mathrm{C}$ for $2 \mathrm{~h}$. Samples were diluted 3000 times with deionized water and the copper concentrations were determined with flame atomic absorption spectrometer (ZEEnit700P, Analytik Jena).

\section{Western blotting}

Cells were lysed with RIPA cell lysis buffer (Beyotime, Shanghai, China), and the protein quantification was determined by BCA Protein Assay Kit (Pierce Biotechnology, Rockford, IL). Equal quantities of protein were resolved by $10 \%$ SDS-PAGE and transferred to polyvinylidene fluoride (PVDF) microporous membrane (Millipore, Boston, MA). After being blocked with 5\% fat-free milk, the membrane was probed with primary antibodies including rabbit anti-MMP-14 (Abcam, ab51074), HAb18 against CD147 (prepared by our laboratory), rabbit anti-CTR1 (Epitomics, 5773-1), rabbit anti-AKT (Cell Signaling Technology, 4685), rabbit anti-phospho(S473)-Akt (Abcam, ab81283). Following incubation with horseradish peroxidase-conjugated goat anti-rabbit or anti-mouse IgG (Santa Cruz, sc-2004 and sc-2005), protein bands on the membrane were visualized using a chemiluminescence kit (Beyotime, Shanghai, China) according to the manufacturer's instructions. Mouse antibody against $\alpha$-tubulin (Abcam, ab80779) or $\beta$-actin (Abcam, ab6276) was used to control for differences in protein loading.

\section{Gelatin zymography}

SMMC-7721 (or MIA PaCa-2) cells and fibroblasts were co-cultured in serum-free medium with different concentrations of $\mathrm{Cu}^{2+}$. The conditioned medium was collected and separated by $10 \%$ SDS-PAGE gels containing $0.1 \%$ gelatin for $30 \mathrm{~min}$ twice. The gels were washed in a $2.5 \%$ Triton X-100 (Sigma) solution at room temperature with gentle agitation. The gels were then soaked in reaction buffer containing $50 \mathrm{mM}$ Tris- $\mathrm{HCl}(\mathrm{pH}$ 7.3), $200 \mathrm{mM} \mathrm{NaCl}$, and $5 \mathrm{mM} \mathrm{CaCl}_{2}$ at $37^{\circ} \mathrm{C}$ for $24 \mathrm{~h}$. The gels were stained with Coomassie Brilliant Blue R250 for $2 \mathrm{~h}$ and destained for $0.5 \mathrm{~h}$. The zones of gelatinolytic activity were revealed by negative staining.

\section{Protein purification}

DNA sequence encoding the extracellular portion of CD147 (residues 22-205) was subcloned into the pET21a vector (Novagen). Point mutations were generated using the site-directed mutagenesis kit (SBS Genetech). Escherichia coli strain Origami (DE3) (Novagen) harboring the construct was cultured in $\mathrm{LB}$ medium at $35^{\circ} \mathrm{C}$ until $\mathrm{OD}_{600}>$ 1.0 , and protein expression was induced with $100 \mu \mathrm{M}$ IPTG at $18^{\circ} \mathrm{C}$. For ${ }^{15} \mathrm{~N}$ isotopically labeling, the bacteria were first grown in LB medium till $\mathrm{OD}_{600}>1.0$, then collected and resuspended in ${ }^{15} \mathrm{~N}$-labeled M9 minimal medium for continuing growth, and $100 \mu \mathrm{M}$ IPTG was added to induce protein expression after $40 \mathrm{~min}$ at $18^{\circ} \mathrm{C}$. The Cells were harvested by centrifugation $24 \mathrm{~h}$ after induction and resuspended in lysis buffer $(50 \mathrm{mM}$ Tris- $\mathrm{HCl}, 40 \mathrm{mM} \mathrm{NaCl}$, $\mathrm{pH} 8.5$ ), then lysed by freezing and thawing, followed by sonication. After centrifugation, the supernatant was applied to ion-exchange column with DEAE-cellulose DE52 (Whatman). Protein was further purified with size exclusion chromatography on a superdex 75 column (Amersham) in $50 \mathrm{mM}$ Tris- $\mathrm{HCl}$ with $50 \mathrm{mM} \mathrm{NaCl}$ (pH 7.5).

\section{NMR titration experiment}

The NMR samples all contained $0.4 \mathrm{mM}$ uniformly ${ }^{15} \mathrm{~N}$ labeled protein in $50 \mathrm{mM}$ Tris- $\mathrm{HCl}, 50$ $\mathrm{mM} \mathrm{NaCl}\left(\mathrm{pH} 7.5\right.$ ) with $90 \% \mathrm{H}_{2} \mathrm{O} / 10 \% \mathrm{D}_{2} \mathrm{O}$. A series of $2 \mathrm{D}{ }^{1} \mathrm{H}^{15}{ }^{15} \mathrm{HSQC}$ spectra with gradually increased $\mathrm{Cu}^{2+}$ concentration $(0.2 \mathrm{mM}, 0.4 \mathrm{mM}, 0.8 \mathrm{mM})$ were collected at $298 \mathrm{~K}$ on a Bruker Avance $500 \mathrm{MHz}$ spectrometer with a triple-resonance cryoprobe. An excess of TM or EDTA ( $4 \mathrm{mM}$ ) was added to the NMR sample for the final 2D ${ }^{1} \mathrm{H}-{ }^{15} \mathrm{~N}$ HSQC spectrum. 


\section{Cross-linking}

Protein $(75 \mu \mathrm{M})$ with or without $\mathrm{Cu}^{2+}(150 \mu \mathrm{M}$, $300 \mu \mathrm{M}$ or $450 \mu \mathrm{M})$ was cross-linked with $150 \mu \mathrm{M}$ ethylene glycolbis (succinimidyl succinate) (EGS) (Pierce) in the reaction buffer (20 mM MOPS, $50 \mathrm{mM} \mathrm{NaCl}, \mathrm{pH}$ 7.2). Before cross-linking by EGS, EDTA was added with the final concentration of $8 \mathrm{mM}$ when it was used. The reaction mixture was incubated at room temperature for $30 \mathrm{~min}$, and then the reaction was quenched by adding Tris (1 M, pH 7.5) to a final concentration of $100 \mathrm{mM}$.

\section{Surface plasma resonance}

Surface plasmon resonance experiments were performed using the ProteOn ${ }^{\mathrm{TM}}$ XPR36 protein interaction array system (Bio-Rad). Briefly, bait CD147 was immobilized on a ProteOn ${ }^{\text {TM }}$ GLC sensor chip (Bio-Rad) by amine coupling. A concentration series of CD147 as analyte $(3.125,6.25,12.5,25$ and $50 \mu \mathrm{M})$ with or without $400 \mu \mathrm{M} \mathrm{Cu}^{2+}$ was injected over the CD147-coated chip for $180 \mathrm{~s}$ at $50 \mu \mathrm{L} / \mathrm{min}$, followed by a $720 \mathrm{~s}$ dissociation time. The chip surface was then regenerated with a pulse of $2 \mathrm{M} \mathrm{NaCl}$ at the end of each cycle. All experiments were performed at $25^{\circ} \mathrm{C}$ in $20 \mathrm{mM}$ Tris- $\mathrm{HCl}$ (pH 7.5), $200 \mathrm{mM}$ $\mathrm{NaCl}, 0.005 \%$ Tween 20 .

\section{Transwell invasion assay}

Chambers with polycarbonate filters with $8-\mathrm{mm}$ nominal pore size (Millipore) coated on the upper side with Matrigel (BD Bioscience, San Jose, CA) was used to assess cell invasiveness. The chambers were placed into a 24-well plate. Cells were trypsinized, resuspended in serum-free media, and seeded at $1 \times 10^{5}$ cells per well in the upper chamber. The lower chamber was filled with $500 \mu \mathrm{L} 1640$ medium containing 15\% FBS with different concentrations of copper chelator TM. Following $16 \mathrm{~h}$ incubation, cells remaining in the upper chamber were completely removed by gently swabbing. The cells that passed through the filter and invaded the lower chamber were stained by crystal violet and counted.

\section{Abbreviations}

HCC, hepatocellular carcinoma; TM, tetrathiomolybdate; MMP, matrix metalloproteinases; PI3K, phosphoinositide 3 kinase; qRT-PCR, quantitative PCR with reverse transcription; NMR, nuclear magnetic resonance; PRE, paramagnetic relaxation enhancement; SPR, surface plasma resonance.

\section{Authors' contributions}

Pengfei Ding, Xin Zhang, Zhi-Nan Chen, Fei Song, and Bin Xia designed the research; Pengfei Ding, Xin
Zhang, Shujuan Jin, Bo Duan, Pengxiang Chu, and Yufei Zhang performed the experiments; Pengfei Ding, Xin Zhang, Fei Song and Bin Xia wrote the manuscript.

\section{ACKNOWLEDGMENTS}

We thank Prof. Peng Shang, Prof. Dehai Liang, Prof. Feng Liu, Prof. Jian-Li Jiang, Ms. Fei Feng, Dr. Jianbo Sun and Dr. Wei Tang for their technical assistance and helpful discussions. All NMR experiments were performed at the Beijing NMR Center and the NMR facility of National Center for Protein Sciences at Peking University.

\section{CONFLICTS OF INTEREST}

The authors declare no conflicts of interest.

\section{FUNDING}

This work was supported by grant 2009CB521700 to Z.-N.C. and B.X., grants 2016YFA0501200 and 2012CB910703 to B.X. from Ministry of Science and Technology of China, and grants 30900234 and 31270015 to F.S. from NSFC of China.

\section{REFERENCES}

1. Kim BE, Nevitt T, Thiele DJ. Mechanisms for copper acquisition, distribution and regulation. Nat Chem Biol. 2008; 4:176-185.

2. Gupte A, Mumper RJ. Elevated copper and oxidative stress in cancer cells as a target for cancer treatment. Cancer Treat Rev. 2009; 35:32-46.

3. Finney L, Vogt S, Fukai T, Glesne D. Copper and angiogenesis: unravelling a relationship key to cancer progression. Clin Exp Pharmacol Physiol. 2009; 36:88-94.

4. Ishida S, Andreux P, Poitry-Yamate C, Auwerx J, Hanahan D. Bioavailable copper modulates oxidative phosphorylation and growth of tumors. Proc Natl Acad Sci USA. 2013; 110:19507-19512.

5. Denoyer D, Masaldan S, La Fontaine S, Cater MA. Targeting copper in cancer therapy: 'Copper That Cancer'. Metallomics. 2015; 7:1459-76.

6. Jain S, Cohen J, Ward MM, Kornhauser N, Chuang E, Cigler T, Moore A, Donovan D, Lam C, Cobham MV, Schneider S, Hurtado Rua SM, Benkert S, et al. Tetrathiomolybdateassociated copper depletion decreases circulating endothelial progenitor cells in women with breast cancer at high risk of relapse. Ann Oncol. 2013; 24:1491-1498.

7. Brewer GJ, Dick RD, Grover DK, LeClaire V, Tseng M, Wicha M, Pienta K, Redman BG, Jahan T, Sondak VK, Strawderman M, LeCarpentier G, Merajver SD. Treatment of metastatic cancer with tetrathiomolybdate, an anticopper, antiangiogenic agent: Phase I study. Clin Cancer Res. 2000; 6:1-10. 
8. Redman BG, Esper P, Pan Q, Dunn RL, Hussain HK, Chenevert T, Brewer GJ, Merajver SD. Phase II trial of tetrathiomolybdate in patients with advanced kidney cancer. Clin Cancer Res. 2003; 9:1666-1672.

9. Henry NL, Dunn R, Merjaver S, Pan Q, Pienta KJ, Brewer G, Smith DC. Phase II trial of copper depletion with tetrathiomolybdate as an antiangiogenesis strategy in patients with hormone-refractory prostate cancer. Oncology. 2006; 71:168-175.

10. Brewer GJ. The promise of copper lowering therapy with tetrathiomolybdate in the cure of cancer and in the treatment of inflammatory disease. J Trace Elem Med Biol. 2014; 28:372-378.

11. Nackos EN, Kornhauser N, Ward MM, Cigler T, Moore A, Andreopoulou E, Chan N, Fitzpatrick V, Schneider SE, Wiener A, Warren JD, Rubinchik A, Willis A, et al. Altering the tumor microenvironment: A phase II study of copper depletion using tetrathiomolybdate (TM) in patients (pts) with breast cancer (BC) at high risk for recurrence. J Clin Oncol. 2015; abstr 11008.

12. Garber K. BIOMEDICINE. Targeting copper to treat breast cancer. Science. 2015; 349:128-129.

13. Brewer GJ. Anticopper therapy against cancer and diseases of inflammation and fibrosis. Drug Discov Today. 2005; 10:1103-1109.

14. Soncin F, Guitton JD, Cartwright T, Badet J. Interaction of human angiogenin with copper modulates angiogenin binding to endothelial cells. Biochem Biophys Res Commun. 1997; 236:604-610.

15. Mandinov L, Mandinova A, Kyurkchiev S, Kyurkchiev D, Kehayov I, Kolev V, Soldi R, Bagala C, de Muinck ED, Lindner V, Post MJ, Simons M, Bellum S, et al. Copper chelation represses the vascular response to injury. Proc Natl Acad Sci USA. 2003; 100:6700-6705.

16. Sen CK, Khanna S, Venojarvi M, Trikha P, Ellison EC, Hunt TK, Roy S. Copper-induced vascular endothelial growth factor expression and wound healing. Am J Physiol Heart Circ Physiol. 2002; 282:H1821-1827.

17. Rigiracciolo DC, Scarpelli A, Lappano R, Pisano A, Santolla MF, De Marco P, Cirillo F, Cappello AR, Dolce V, Belfiore A, Maggiolini M, De Francesco EM. Copper activates HIF-1alpha/GPER/VEGF signalling in cancer cells. Oncotarget. 2015; 6:34158-34177. doi: 10.18632/oncotarget.5779.

18. Garber K. Cancer's copper connections. Science. 2015; 349:129.

19. MacDonald G, Nalvarte I, Smirnova T, Vecchi M, Aceto N, Dolemeyer A, Frei A, Lienhard S, Wyckoff J, Hess D, Seebacher J, Keusch JJ, Gut H, et al. Memo is a copperdependent redox protein with an essential role in migration and metastasis. Sci Signal. 2014; 7:ra56.

20. Brady DC, Crowe MS, Turski ML, Hobbs GA, Yao X, Chaikuad A, Knapp S, Xiao K, Campbell SL, Thiele DJ, Counter CM. Copper is required for oncogenic BRAF signalling and tumorigenesis. Nature. 2014; 509:492-496.
21. Erler JT, Bennewith KL, Nicolau M, Dornhofer N, Kong C, Le QT, Chi JT, Jeffrey SS, Giaccia AJ. Lysyl oxidase is essential for hypoxia-induced metastasis. Nature. 2006; 440:1222-1226.

22. Balter V, Nogueira da Costa A, Bondanese VP, Jaouen K, Lamboux A, Sangrajrang S, Vincent N, Fourel F, Telouk P, Gigou M, Lecuyer C, Srivatanakul P, Brechot C, et al. Natural variations of copper and sulfur stable isotopes in blood of hepatocellular carcinoma patients. Proc Natl Acad Sci USA. 2015; 112:982-985.

23. Finney L, Mandava S, Ursos L, Zhang W, Rodi D, Vogt S, Legnini D, Maser J, Ikpatt F, Olopade OI, Glesne D. $\mathrm{X}$-ray fluorescence microscopy reveals large-scale relocalization and extracellular translocation of cellular copper during angiogenesis. Proc Natl Acad Sci USA. 2007; 104:2247-2252.

24. Zhu D, Wang Z, Zhao JJ, Calimeri T, Meng J, Hideshima T, Fulciniti M, Kang Y, Ficarro SB, Tai YT, Hunter Z, McMilin D, Tong H, et al. The Cyclophilin A-CD147 complex promotes the proliferation and homing of multiple myeloma cells. Nat Med. 2015; 21:572-580.

25. Crosnier C, Bustamante LY, Bartholdson SJ, Bei AK, Theron M, Uchikawa M, Mboup S, Ndir O, Kwiatkowski DP, Duraisingh MT, Rayner JC, Wright GJ. Basigin is a receptor essential for erythrocyte invasion by Plasmodium falciparum. Nature. 2011; 480:534-537.

26. Wright KE, Hjerrild KA, Bartlett J, Douglas AD, Jin J, Brown RE, Illingworth JJ, Ashfield R, Clemmensen SB, de Jongh WA, Draper SJ, Higgins MK. Structure of malaria invasion protein RH5 with erythrocyte basigin and blocking antibodies. Nature. 2014; 515:427-430.

27. Bernard SC, Simpson N, Join-Lambert O, Federici C, LaranChich MP, Maissa N, Bouzinba-Segard H, Morand PC, Chretien F, Taouji S, Chevet E, Janel S, Lafont F, et al. Pathogenic Neisseria meningitidis utilizes CD147 for vascular colonization. Nat Med. 2014; 20:725-731.

28. Ait-Ali N, Fridlich R, Millet-Puel G, Clerin E, Delalande F, Jaillard C, Blond F, Perrocheau L, Reichman S, Byrne LC, Olivier-Bandini A, Bellalou J, Moyse E, et al. Rod-derived cone viability factor promotes cone survival by stimulating aerobic glycolysis. Cell. 2015; 161:817-832.

29. Iacono KT, Brown AL, Greene MI, Saouaf SJ. CD147 immunoglobulin superfamily receptor function and role in pathology. Exp Mol Pathol. 2007; 83:283-295.

30. Xiong L, Edwards CK 3rd, Zhou L. The biological function and clinical utilization of CD147 in human diseases: a review of the current scientific literature. Int J Mol Sci. 2014; 15:17411-17441.

31. Toole BP. Emmprin (CD147), a cell surface regulator of matrix metalloproteinase production and function. Curr Top Dev Biol. 2003; 54:371-389.

32. Yan L, Zucker S, Toole BP. Roles of the multifunctional glycoprotein, emmprin (basigin; CD147), in tumour progression. Thromb Haemost. 2005; 93:199-204. 
33. Tang X, Guo N, Xu L, Gou X, Mi M. CD147/EMMPRIN: an effective therapeutic target for hepatocellular carcinoma. J Drug Target. 2012.

34. Grass GD, Toole BP. How, with Whom, and When: An Overview of CD147-mediated Regulatory Networks Influencing Matrix Metalloproteinase Activity. Biosci Rep. 2015.

35. Kessenbrock K, Plaks V, Werb Z. Matrix metalloproteinases: regulators of the tumor microenvironment. Cell. 2010; 141:52-67.

36. Yoshida S, Shibata M, Yamamoto S, Hagihara M, Asai N, Takahashi M, Mizutani S, Muramatsu T, Kadomatsu K. Homo-oligomer formation by basigin, an immunoglobulin superfamily member, via its N-terminal immunoglobulin domain. Eur J Biochem. 2000; 267:4372-4380.

37. Liao CG, Kong LM, Song F, Xing JL, Wang LX, Sun ZJ, Tang H, Yao H, Zhang Y, Wang L, Wang Y, Yang XM, Li Y, et al. Characterization of basigin isoforms and the inhibitory function of basigin-3 in human hepatocellular carcinoma proliferation and invasion. Mol Cell Biol. 2011; 31:2591-2604.

38. Cui HY, Guo T, Wang SJ, Zhao P, Dong ZS, Zhang Y, Jiang JL, Chen ZN, Yu XL. Dimerization is essential for HAb18G/ CD147 promoting tumor invasion via MAPK pathway. Biochem Biophys Res Commun. 2012; 419:517-522.

39. Kumar P, Yadav A, Patel SN, Islam M, Pan Q, Merajver SD, Teknos TN. Tetrathiomolybdate inhibits head and neck cancer metastasis by decreasing tumor cell motility, invasiveness and by promoting tumor cell anoikis. Mol Cancer. 2010; 9:206.

40. Friedl P, Wolf K. Tube travel: the role of proteases in individual and collective cancer cell invasion. Cancer Res. 2008; 68:7247-7249.

41. Shen Q, Lee ES, Pitts RL, Wu MH, Yuan SY. Tissue inhibitor of metalloproteinase-2 regulates matrix metalloproteinase-2-mediated endothelial barrier dysfunction and breast cancer cell transmigration through lung microvascular endothelial cells. Mol Cancer Res. 2010; 8:939-951.

42. Ostrakhovitch EA, Lordnejad MR, Schliess F, Sies H, Klotz LO. Copper ions strongly activate the phosphoinositide-
3-kinase/Akt pathway independent of the generation of reactive oxygen species. Arch Biochem Biophys. 2002; 397:232-239.

43. Eckers A, Reimann K, Klotz LO. Nickel and copper ioninduced stress signaling in human hepatoma cells: analysis of phosphoinositide 3'-kinase/Akt signaling. Biometals. 2009; 22:307-316.

44. Hsieh CH, Cheng LH, Hsu HH, Ho TJ, Tu CC, Lin YM, Chen MC, Tsai FJ, Hsieh YL, Huang CY. Apicidinresistant HA22T hepatocellular carcinoma cells strongly activated the $\mathrm{Wnt} /$ beta-catenin signaling pathway and MMP-2 expression via the IGF-IR/PI3K/Akt signaling pathway enhancing cell metastatic effect. Biosci Biotechnol Biochem. 2013; 77:2397-2404.

45. Schlegel J, Redzic JS, Porter CC, Yurchenko V, Bukrinsky M, Labeikovsky W, Armstrong GS, Zhang F, Isern NG, DeGregori J, Hodges R, Eisenmesser EZ. Solution characterization of the extracellular region of CD147 and its interaction with its enzyme ligand cyclophilin A. J Mol Biol. 2009; 391:518-535.

46. Pushkarsky T, Zybarth G, Dubrovsky L, Yurchenko V, Tang H, Guo H, Toole B, Sherry B, Bukrinsky M. CD147 facilitates HIV-1 infection by interacting with virusassociated cyclophilin A. Proc Natl Acad Sci USA. 2001; 98:6360-6365.

47. Song F, Zhang X, Ren XB, Zhu P, Xu J, Wang L, Li YF, Zhong N, Ru Q, Zhang DW, Jiang JL, Xia B, Chen ZN. Cyclophilin A (CyPA) induces chemotaxis independent of its peptidylprolyl cis-trans isomerase activity: direct binding between CyPA and the ectodomain of CD147. J Biol Chem. 2011; 286:8197-8203.

48. Marchiq I, Albrengues J, Granja S, Gaggioli C, Pouyssegur J, Simon MP. Knock out of the BASIGIN/ $\mathrm{CD} 147$ chaperone of lactate/H+ symporters disproves its pro-tumour action via extracellular matrix metalloproteases (MMPs) induction. Oncotarget. 2015; 6:24636-24648. doi: 10.18632/oncotarget.4323.

49. Grubman A, White AR. Copper as a key regulator of cell signalling pathways. Expert Rev Mol Med. 2014; 16:e11. 